\title{
A Study of Developing an Attitude Scale Towards Authentic Learning Environments and Evaluation
}

\author{
Murat Çetinkaya \\ Correspondence: Murat Çetinkaya, Unye Vocational School, Department of Computer, Ordu University, Ordu, Turkey.
}

Received: December 25, 2017

Accepted: March 20, 2018 Online Published: March 23, 2018

doi:10.11114/jets.v6i4.2887

URL: https://doi.org/10.11114/jets.v6i4.2887

\begin{abstract}
The aim of the research is to improve a valid and reliable attributing scale which identifies authentic learning environments and evaluation attributes of the science teacher candidates. The study has been designed on the base of validity and reliability of the scale developed to evaluate the authentic learning environments. The research group is consisted of teacher candidates at education faculty of Ordu University $(n=202)$. The study has been carried out by the teacher candidates being trained in 2 nd and 3 rd class of science, mathematics, and elementary teaching classrooms at education faculty. A descriptive factor analysis has been carried out to ensure the structural validity of the scale. The test of Kaiser-Meyer-Olkin (KMO) and Bartlett has been implemented to check the reliability for the sampling size and factor analysis of the obtained data. In addition, an anti-image correlation matrix has been checked. The latest 20-item scale regulated according to the results of the analysis has been formed. The reliability coefficient (Cronbach Alpha) has been determined as 0.931 . Confirmatory factor analysis has been applied to the scale which was determined as two factors. From the results of the analysis, it is expressed that the attitude scale created for the authentic learning and measurement is a valid and reliable.
\end{abstract}

Keywords: attitude, authentic learning, evaluation, validity, reliability

\section{Introduction}

In science education, in-class theoretical learning is of vital importance. As well as in-class formal learning, science education needs to be associated with its reflection in everyday life. Once this relationship is established, it will be much easier for the students to interpret the information. Students who cannot establish this connection will tend to memorize the theoretical knowledge rather than interpret it. Such situation is undesirable in science teaching. If the students associate the theoretical learning in school with their daily lives, interpretation of new and the related learning will be much easier. It is thought that the use of authentic learning environments will be effective in creating learning environments where permanent learning is provided (Fook and Sidhu, 2010).

Authentic learning is real life learning. It is a style of learning that encourages students to create a tangible, useful product to be shared with their world and thus providing meaningful and permanent learning. It is necessary to create learning environments that enable individuals to learn by living and to make a connection with real life. In this context, teachers can positively influence their student attitudes, behaviors and achievements if they create authentic learning environments appropriate for the class. In authentic learning, students actively perform collaborative problem solving activities. This process will play an effective role in helping students to develop and use high-level thinking skills. As it is seen, teachers have great responsibilities in creating authentic learning environments. Teachers' attitudes and knowledge will be the most important factor in planning the process. Teachers need to have the skills to solve the problems that can be encountered in everyday life. Hereby, they may be a guide to their students in solving real-world problems (Bektaş and Horzum, 2010).

In authentic learning, the teacher gives the students some tasks related to real life. For example, although a teacher teaches the topic of heat insulation theoretically very well in the classroom, this may not get a meaningful response to the student. In authentic learning, the teacher gives the students with non-class tasks as well as formal teaching in the classroom environment. These tasks are expected to be directly related to everyday life. The students may be asked to make a detailed analysis of the heat insulation of their houses. The students may get information from the family members or the people around them when fulfilling the task. The process should be planned by the student single-handedly and if needed, he/she may ask for help. After fulfilling the duty (task) given by the teacher, the students 
are asked to report and share it with his classmates in the classroom. This process should be consciously planned by the teacher, the association between the tasks given and the daily life should be well established and the guidance should be maintained during the whole process.

Despite some similarities, there are also significant differences between the context-based approach and authentic learning. In the context (life)-based approach, a problem related to everyday life is used in the lessons through stories. In this approach, the courses are taught according to certain models (ARCS, REACT). In authentic learning, the solutions are flexible. The student can even develop solutions that are specific to their cultural values. In contrast to context-based learning in which there are artificial connections established with real life, students may find solutions in their own life in authentic learning (Dewey, 2007; Gürdoğan and Aslan, 2016).

In authentic learning, the evaluation of the task assigned to the students through classical assessment methods such as multiple choice tests, written or oral exams will not provide sufficient information about the process. On the other hand, the evaluation of the authentic tasks given to the student should be continuous from the beginning of the process until the final stage of the production. The most effective method in evaluating the process is the use of alternative assessment tools (Kılıç, 2014). Not only the cognitive but also the affective and psychomotor developments of the students should be evaluated as a whole. The use of alternative assessment evaluation techniques such as portfolio, concept maps, self or peer evaluation, poster and interviews are recommended in the evaluation of high-level cognitive features of the students such as data collection, analysis and presentation of the results (Küçüktepe, 2010; K1lıç, 2014). In authentic evaluation, it is important for the students to perform, produce and share the tasks. It is essential to measure the performance of the student and to examine the formation process of the resulting product entirely (Tan, 2009).

Authentic evaluation requires much more time than classical evaluation techniques, and therefore the evaluation needs to be well planned. If the teacher is inexperienced or he/she has a lack of knowledge about authentic evaluation, the evaluation then will be ineffective. Here, the teacher is expected to be well-equipped and a good mentor to direct the students (Fer and Curık, 2007). Teachers play a crucial role in establishing and evaluating authentic learning environments. In this context, determining the teachers' attitudes towards authentic learning will be an important reference for the development of new curricula. The aim of this study is to develop a valid and reliable attitude scale for the determination of science teacher candidates' attitudes towards authentic learning environments and its evaluation.

\section{Method}

\subsection{Study Design}

This study was designed to assess the validity and reliability of the attitude scale developed for authentic learning environments and evaluation.

\subsection{Sample Group}

The sample group consists of the teacher candidates $(n=202)$ attending Ordu University, Faculty of Education (Table 1). The study was conducted with prospective teachers receiving education in the second and third grades of science, mathematics and classroom teaching departments.

Table 1. Frequency Distribution of the Teacher Candidates Constituting the Research Sample

\begin{tabular}{lll}
\hline Ordu University, Faculty of Education & N & \% \\
\hline Science Teaching & 70 & 35 \\
Mathematics Teaching & 65 & 32 \\
Classroom Teaching & 67 & 33 \\
\hline Total & 202 & 100 \\
\hline
\end{tabular}

When the size of sampling is 100 and higher than 100 "low", and when it is 200 and higher than 200 "medium", and when it is 300 and higher than 300 "good", and when it is 500 and higher than 500 "very good", and when it is 1000 and higher than 1000 "excellent" are specified (Comrey and Lee, 1992). Besides, it is pointed out that the number of the item should be 5 or 10 times for the size of sampling (Tavşanc1l, 2002). For the scale developing study consisting of 20 items it can be said that the number of sampling is $(\mathrm{n}=202)$ at "medium" level.

\subsection{Preparation of Evaluation Instrument}

This scale was developed to identify teachers' attitudes towards authentic learning environments and evaluation. Fifteen 4th grade teacher candidates not participating in the student (science, mathematics and classroom teaching departments) were selected and subjected to open-ended questions. Written responses were examined and used to create scale items. In addition, a literature review intended for authentic environment and evaluation has been performed. The results of the interview and literature review have been evaluated and original attitude expressions have been formed by the researcher. A five-point Likert-type scale consisting of a total of 40 items (18 negative and 22 positive) that cover authentic learning environments and authentic evaluation was prepared. When preparing the scale items, teachers' 
attitudes including "knowing, using, and applying" towards authentic learning and evaluation were used. The answers in the scale were as follows; "strongly agree 5", "agree: 4", "undecided 3", "disagree 2", "totally disagree 1". Negative items in the scale were graded using reverse recoding. Opinions of two field-experts were asked and necessary corrections were made considering the feedbacks. The 3 items in the scale have been expressed to be at low level in measuring the attitudes intended for authentic environments and evaluation. Three items were excluded from the scale on expert opinions. The final scale consisting of 37 items was applied to the teacher candidates.

\subsection{Analysis of the Data}

For construct validity of the scale, an exploratory factor analysis was performed using a "SPSS 19" package program. Kaiser-Meyer-Olkin (KMO) and Bartlett's test were used to check the adequacy of the obtained data to factor analysis and sample size. In addition, anti-image correlation matrix was also used. The mean, standard deviation, total item correlation of the scale items and values of factor loadings were tabulated and the fitness of the items was checked. Confirmatory factor analysis was also applied using an "IBM Amos 24" package program. For reliability analysis of the scale, Cronbach's Alpha value was calculated.

\section{Results}

For factor analysis, anti-image correlation analysis was performed. In anti-image correlation analysis, the value of each Measures of Sampling Adequacy - MSA should be necessarily above 0.45 and the items below this value should be removed from the analysis (Büyüköztürk, Bökeoğlu and Köklü, 2009). Items with a value below 0.50 were excluded from the scale. In anti-image correlation analysis which was performed after removing the items from the scale, items values ranged between 0.846 and 0.950 (Table 2).

Table 2. Anti Image Correlation Analysis Results

\begin{tabular}{|c|c|c|c|c|c|c|c|c|c|c|c|c|c|c|c|c|c|c|c|c|c|c|c|c|c|c|c|c|}
\hline & $\bar{\xi}$ & ๘ & ळ & ळ & \% & ६ & ஸे & ळ & 嗉 & 윻 & $\bar{\omega}$ & $\frac{\pi}{\infty}$ & $\frac{2}{\infty}$ & 5 & $\frac{\infty}{\infty}$ & $\div$ & $\bar{\infty}$ & $\frac{\infty}{\infty}$ & $\frac{2}{\infty}$ & స్థి & $\bar{\Phi}$ & స్ఞ & $\widetilde{\varpi}$ & స్ల & 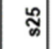 & 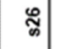 & స్ & $\mathbb{్}$ \\
\hline s1 & $.903^{\circ}$ & -053 &,- 049 &, 091 & . 176 & {$[-, 066$} & 125 &,$- 018 \mid$ & | & - 102 & $-0,092$ & 094 & {$[-080$} &, 068 & 151 & .073 &,$- 041-$ &, 020 & | & {$[-, 071$,} & 062 &,$- 059 \mid$ & {$[-, 263 \mid$} & 054 & -067 &,$- 087 \mid$ & . 164 & .170 \\
\hline s2 & -053 & . $.892^{\circ}$ & -.585 & 029 & .030 & .146 & -1111 & .073 & .084 & .042 &,- 226 & -222 & {$[-074$} &,- 168 & -059 &,- 037 &,- 022 & 015 & .033 & .085 & .071 & .058 &,- 012 & 107 & 1. 160 & .065 & . 161 &,- 018 \\
\hline s3 & .049 & - 585 & $.880^{\circ}$ &, 336 & -200 & -083 & .079 &,- 053 & - 012 & -101 & .042 & 163 & 200 & .150 & .029 &,- 019 & .000 & 053 & -127 & .004 & .025 &,- 005 & .086 & .130 & -157 & .067 . & 162 & -170,- \\
\hline$\$ 4$ & -091 & $\mid .029$ & -.336 & $921^{\circ}$ & .088 & -031 & -011 & $-0,016$ & 106 & - & .067 & 169 & - 1990 & .081 & .023 &,- 224 & .122 & .093. & - 121 & .005 & .044 & {$[-023 \mid$,} & .085 & 016 & $\mid-103$ & .038 & ,191. &,- 068 \\
\hline s5 & 176 & 030 & -200 & 088 & $850^{\circ}$ & .082 & , 195 & $\mid-233$ & - 042 & .019 &,- 071 & -059 & {$[-487]$} &,- 152 & 232 & , 055 &,$- 019 \mid$ & -105 & .029 & $-0,057 \mid$ & . & , 129 & $|-087|$ & 035 & | & -077 & .023, & 116. \\
\hline s6 &, 066 & , 146 & $-0,03$ & -031 & .082 & $.915^{5}$ & -431 &, 086 & ,092 & |187 &,$- 117 \mid$ & -075 & .042 &,- 152 & 194 & $-1,160$ &,$--101 \mid$ & -148 & -025 &,- 009 & -109 &,- 041 & -187 &,- 052 & . 188 &,- 151 & 024 & ,013. \\
\hline s7 & 125 & -111 & .079 & 011 & -195 & -431 & $.908^{\circ}$ & -038 & -014 & -299 & -012 & .034 & |098. & 1.129 & -120 & -020 &,- 054 & 184 & -151 & . 1499 & 018 &, 164 &, 071 & .021 & -057 & . 093 & -074 & .015 \\
\hline s8 & ,018 & ,073 & 053 &, 016 & -233 & .086 & ,038 & $910^{2}$ & 124 & -040 & -273 & .139 & .025 & .075 &, 054 & -262 & .223 & -108 & 042 &,- 062 & -115 & {$[-, 005]$,} &, 006 &, 146 & $\mid .079$ & 031. & 037 & -, 053 \\
\hline s9 & , 127 & -084 & ,012 & 106 & , 042 & $-0,092$ & -014 & 124 & $936^{a}$ & -1222 & -0.025 & .064 & -047 & .015 & -116 &,- 225 & .087. & 128 & - 230 &, 074 & 074, & {$[084$,} &, 043 & ,241 & 271 &,- 208 - & -089, & ,088 \\
\hline s10 & , 102 & .042 & - 101 & ,069 & .019 & 187. & 299 & -040 & - 122 & $847^{\circ}$ & .026 & -183 & . 040 &,$--277 \mid$ & 124 & , 127 & $-0,022$. & -295 & .081 & $-0,049$ & 126 & 261 & -167 & , 121, & 035 & , 030 & 091 & 051 \\
\hline s11 & -0992 & 226, & .042 & .067 & , $071-$ & ,117 & .012 & , 273 & .025 & .026 & $.950^{\circ}$ & 134 & . 01. &, 028 & .083 & {$[-, 073$} & $-0,043$. & , 167 & , 124 & 年, & 011 & , 124, & .059. & .032 & 139 & - 260 & .050 . & -,037 \\
\hline $\mathbf{s} 12$ & 1094 & - 2222 & 163 & 169 & .059 & $-0,075$ & 034 & , 139. & .064 & 183, & 134 & $.857^{2}$ & -287 & .087 & .002 & - 146 & .202 & -055 & |195. & .116 &., 092 & $-079 \mid$ & , 068 &, 044 & 146. & $-0,017$ & 050 & -, 029 \\
\hline$s 13$ & -080 & -074 & 200 & , 190 & $-4,487$ & .042 & 098 & .025 & ,047 & .040 & .091 & -287 & $.868^{\circ}$ &,- 215 & 037 & -080 &,- 055 & -103 & .035 &,- 024 & -103 & {$[-, 075]$,} & $, 023\}$ & , 103 & $\mid 076$ &,- 008 & 033 & -, -014 \\
\hline s14 & 1068 & -168 - & 150 & .081 & . 152 & -152 & 129 & . 075 & .015 & - 2777 & .028 & 087 & 215 & $.8711^{2}$ & .235 & -055 & 136 & .026 & .017 & -195 & .099 & , 043 & .032 & .005 & .007 & .026 & , 066 & 047 \\
\hline s15 & 151 & -059 & -029 & .023 & .232 & .194 & , 120 & $-0,054$ & -116 & , 124 & .083 & .002 & . &,$- 235 \mid$ & $.908^{2}$ & -223 &,$- 207-$ & -284 & .068 & .150 &,- 238 & {$[-, 078 \mid$} & {$[-060 \mid$} & 016 & ; &,- 202 & .027 &,- 067 \\
\hline$s 16$ & .073 & -037 & $-0,019$ &,- 224 & .055 & , 160 & .020 &,- 262 & -225 & .127 &,- 073 & . 1466 &,- 080 &,$- 055 \mid$ & -223 & $918^{\circ}$ & $|-423|$ & .028 & .053 &,$- 057 \mid$ & .078 & $.027 \mid$ & {$[-, 211 \mid$,} & 244 & . 091 & -006 & , 114 & .056 \\
\hline s17 & -041 & -022 & .000 & 122 & ,019. & -101 & -054 & .223 & ,087 & -022 & $-0,043$ & 202 & - & .136 & ,207 & -.423 &, $920^{\circ}$, & .072 & -215 &,- 188 &,- 064 & , 045 &,- 029 & -133 & -132 & 091.01 & ,019 &,- 010 \\
\hline$s 18$ & .020 & .015 & .053 & ,093 & $=105$ &,- 148 & 184 & , 108 & .128 & 295 &, 167 & -055 & -103 & .026 &, 284 & ,028 & .072 & $.892^{2}$ & .054 & 030 & , & {$[-155 \mid$,} & ,084 & 012 & .015 & 194 & ,012. & .108 \\
\hline$s 19$ & -185 & .033 & -127 &, 121 & .029 & ,025 & - 151 &, 042 & - 230 & 081 & , 124 & , 195 & .035 & {$[-, 017$} & 0.068 & .053 &,$- 215 \mid$ &,- 054 & $.945^{\circ}$ & -.125 & -018 &,$- 179 \mid$, & , 095 & 137 & |039 & . 051 & 019 &,- 047 \\
\hline s20 & -071 & .085 & .004 & .005 & -057 &,- 009 & 149 & -062 & .074 & , 049 & -010 & 116 &,- 024 & -195 & 150 & -057 &,- 188 & .030 & 125 & $.857^{2}$ & -191 & , & .178 & 404 & {$[-003$} & .052 & , 078 &,- 076 \\
\hline s21 & .062 & ,071 & -, 025 & ,, 044 & , 021 & | & 018 &,- 115 & .074 & , 126 & -011 & . 092 & {$[-103$} & $\mid 099$ & -238 & , 078 &,$- 064 \mid$ & & , 018 &,- 191 & $.927^{\circ}$ & 076 &,- 173 & -121 & . 067 & 150 & 0,017 & 138. \\
\hline s22 & .059 &,- 058 & .005 &, 023 & , 129 &, 041 & 164 &, 005 & ,084 & 261 & , 124 & .079 &,- 075 & -043 & -078 & 0,027 & , 045 & , 155 &, 179 &,$- 098 \mathrm{~b}$ & -076 & $949^{\circ}$ & 045 & .008 & 200 & 003 & 030 & .016 \\
\hline $\mathrm{s} 23$ & -263 & -012 & .086 & 085 & -087 & $-1,187 \mid$ & 071 & .006 & .043 & , 167 & .059 & 068 & . 023 & .032 & .060 & -211 & $-029\}$ & .084 & .095 &, 178 & , 173 & , & $.924^{2}$ & , 108 & 334 & ;,014 & .032 . & -198 \\
\hline s24 & .054 & 107 & , 130 & 016 & ,035 & -052 &, 021 & , 146 & -241 & 121, & .032 & , 044 & -103 & $\mid-, 085$ & . 016 & 244 & {$[-133 \mid$} & 012 & .137. & {$[-404\}$} &,- 121 &, 008 & {$[-108 \mid$} & $.863^{\circ}$ & .095 &,- 221 & 108 & .011 \\
\hline $\mathrm{s} 25$ & .067 & 160 & , 157 & , 103 & -107 & 188 &, 057 & .079 & -211 & , 035 & -139 & , 146 & .076 & .007 & , 109 & .091 &,- 132 &,- 015 & .039 &,$- 003 \mid$ & .067 & 20 & ,334 & 095 & ,929 & .038 & 031 & , 015 \\
\hline s26 & ,, 087 & .065 & .067 & 038 & $-0,077$ &,- 151 & .093 & .031 & |-208 & {$[-030]$} &,- 260 & 5,017 & {$[-008$} & .026 & -202 & {$[-, 006$} & . 091 & 194 & .051 & .052 & 150 & 00 & 14 & ,221 & .038 & $881-$ & 249 & -306 \\
\hline s27 & 164 & , 161, & 162 & 191; & .023. & .024 &, 074 &, 037 & ; & .091 & -.050 & .050 & .033 & {$[-066$} & .027 & .114 & $-0,019$ & -012 & . 019 &, $078 \mathrm{P}$ &,- 017 & & {$[-032$} & .108 & 031 & -249 & $846^{\prime \prime}$ & -188 \\
\hline & & & & & & 012 & & & 088 & & & & & & 067 & 056 & 010 & 108 & & 076 & 138 & & & 011 & 016 & .306 & 188 & $911^{\circ}$ \\
\hline
\end{tabular}

Kaiser-Meyer-Olkin (KMO) and Bartlett's test were used to check adequacy of the obtained data to factor analysis and sample size (Table 3). KMO value was found to be 0.903. It was stated that KMO value of 1 (around 1) indicates that the sample is adequate (Şencan, 2005; Kalayc1, 2010). This result showed that the sample adequacy is marvelous. In addition, according to Barlett's test results, inter-class correlation was found to be high. Kaiser-Meyer-Olkin (KMO) and Bartlett's test were used to check adequacy of the obtained data to factor analysis and sample size (Table 3). KMO value was found to be 0.903 . It was stated that KMO value of 1 (around 1) indicates that the sample is adequate (Şencan, 2005; Kalayc1, 2010). This result showed that the sample adequacy is marvelous. In addition, according to Barlett's test results, inter-class correlation was found to be high $\left(\mathrm{x}^{2}=2350,067 ; \mathrm{p}<0.01\right)$. 
Table 3. KMO and Bartlett's Test Results

\begin{tabular}{lll}
\hline Kaiser-Meyer-Olkin (KMO) & & .903 \\
\hline \multirow{3}{*}{ Bartlett's Test of Sphericity } & Approx. Chi-Square & 2350.067 \\
& df & 378 \\
& Sig. & .000 \\
\hline
\end{tabular}

The factor load value of 0.45 or higher is a good measure for selection (Büyüköztürk, Bökeoğlu and Köklü, 2009). The factor load limit value was set at .50. In the exploratory factor analysis, of the items that undergo varimax vertical rotations, those with factor values less than .50 or close to .50 were excluded $(14,26,30$ and 40$)$. In addition, as well as item 34 that gets close values in more than one sub-dimensions and items 2, 3, 4, 7, 20, 24, 26, 27, 28 and 36 consisting of 3 and less items were excluded from the scale. After excluding the items from the scale, the varimax vertical rotation analysis was repeated. The results of the repeated analysis indicate that the scale is 2-factor (Figure 1). A similar situation was also observed when the factor loads and distributions of the scale were examined.

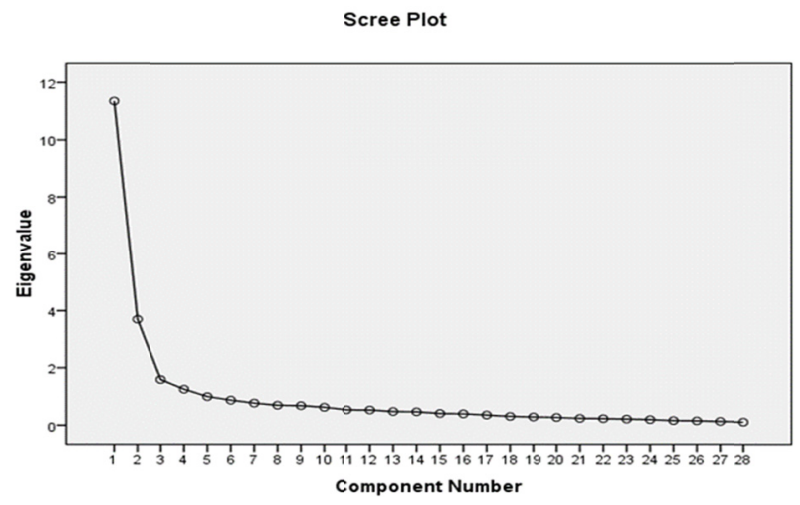

Figure 1. Eigenvalue-Factor Graph

It is seen in Figure 1 that the graph reaches a plateau from the third factor. These items (26, 27 and 28) were excluded from the scale due to the weak decisive effect on attitude. Considering the factors and factor loads, the scale is considered as two-factor scale. Factor groups and factor loads of the scale items are shown in Table 4.

Table 4. Factors and Factor Loads

\begin{tabular}{lll}
\hline \multirow{2}{*}{ Scale Items } & \multicolumn{2}{l}{ Factors and Factor Loads } \\
\cline { 2 - 3 } & $\mathbf{1}$ & $\mathbf{2}$ \\
\hline $\mathrm{m} 14$ & .822 & \\
$\mathrm{~m} 13$ & .807 & \\
$\mathrm{~m} 16$ & .786 & \\
$\mathrm{~m} 8$ & .779 & \\
$\mathrm{~m} 20$ & .767 & \\
$\mathrm{~m} 6$ & .766 & \\
$\mathrm{~m} 3$ & .762 & \\
$\mathrm{~m} 18$ & .758 & \\
$\mathrm{~m} 19$ & .714 & \\
$\mathrm{~m} 4$ & .701 & \\
$\mathrm{~m} 12$ & .700 & .839 \\
$\mathrm{~m} 1$ & .643 & .804 \\
$\mathrm{~m} 10$ & & .733 \\
$\mathrm{~m} 2$ & & .704 \\
$\mathrm{~m} 9$ & & .703 \\
$\mathrm{~m} 15$ & & .684 \\
$\mathrm{~m} 5$ & & .666 \\
$\mathrm{~m} 7$ & & .636 \\
$\mathrm{~m} 11$ & & \\
$\mathrm{~m} 17$ & & \\
\hline
\end{tabular}


In Table 4 it is seen that the items of the attitude are positive expressions for the factor 1 , and negative expressions for the factor 2. While the "Positive Approach", which is the 1st factor of the scale consists of 12 items $(1,3,4,6,8,12,13$, $14,16,18,19$ and 20), the variance was found to be as $44.071 \%$. The second factor, "Negative Approach", consists of 8 items $(2,5,7,9,10,11,15$ and 17) and the variance was found to be as $14.763 \%$ (Table 5).

Table 5. Factor Eigenvalues

\begin{tabular}{lcccccc}
\hline \multirow{2}{*}{ Factors } & \multicolumn{3}{c}{ Initial Eigenvalues } & \multicolumn{3}{c}{ Rotation Sums of Squared Loadings } \\
\cline { 2 - 6 } & Total & \% of Variance & Cumulative \% & Total & \% of Variance & Cumulative \% \\
\hline 1 - Positive Approach & 8.814 & 44.071 & 44.071 & 7.093 & 35.464 & 35.464 \\
2 - Negative Approach & 2.953 & 14.763 & 58.834 & 4.674 & 23.370 & 58.834 \\
\hline
\end{tabular}

Table 5 shows the results of exploratory factor analysis. The total variance explained by 2 factors is $58.834 \%$. The value of the variance explained is interpreted as an indicator of how well the relevant attitude is measured. It can be said that the total variance value (58.834\%) is above the acceptable variance value (Büyüköztürk, Bökeoğlu and Köklü, 2009).

Reliability analysis of all the factors and the scale was performed and the reliability coefficient (Conbach alpha) values are presented in Table 6.

Table 6. Reliability Coefficients of the Factors and the Scale

\begin{tabular}{lccc}
\hline Factors & $\begin{array}{c}\text { Number } \\
\text { of items }\end{array}$ & $\begin{array}{c}\text { Reliability Coefficient } \\
\text { (cronbach alpha) }\end{array}$ & \% of variance \\
\hline 1 - Positive Approach & 12 & 0.935 & 44.071 \\
2 - Negative Approach & 8 & 0.870 & 14.763 \\
\hline Total & 20 & 0.931 & 58.834 \\
\hline
\end{tabular}

When Table 6 is analyzed, it is seen that the variance of "Positive Approach" factor consisting of 12 items is 44.071 and the reliability coefficient (Cronbach Alpha) is .935. These values were 14.763 and .870 respectively in "Negative Approach" factor that consists of 8 items. The reliability coefficient of the 20 -item scale was found to be .931 .

The data on mean, standard deviation, total-item correlation and factor load values of the scale items are presented below.

It is seen from the Table 7 that item 19, which has the lowest mean value, has a value of 3.26 whereas item 5, which has the highest mean value, has a value of 4.62. In addition, the correlation of the total score of the scale and the score of each item was calculated. In total-item correlation values, the lowest correlation was observed in item 27 ( $\mathrm{r}=.313$, $\mathrm{p}<0.01)$ and the highest correlation was observed in item $16(\mathrm{r}=.749, \mathrm{p}<0.01)$ which indicates a moderate and high correlation between items. 
Table 7. Mean Standard Deviation, Total-Item Correlation and Factor Load Values of the Scale Items

\begin{tabular}{|c|c|c|c|c|c|}
\hline \multicolumn{2}{|c|}{ Scale Items } & $\sum_{\Sigma}^{\Xi}$ & 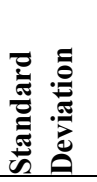 & 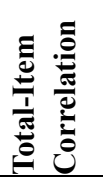 & 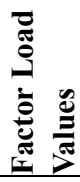 \\
\hline \multicolumn{6}{|c|}{ Factor 1 - Positive Approach } \\
\hline 1 & I love creating authentic learning environments when teaching unit topics. & 3.42 & 1.077 & $.498 *$ & .643 \\
\hline 3 & I would like to use authentic learning environments in all my courses. & 3.49 & 1.112 & $.666^{*}$ & .762 \\
\hline 4 & Authentic learning method should be used in other courses (mathematics, science). & 3.79 & 1.008 & $.624 *$ & .701 \\
\hline 6 & I think that authentic learning method can be effectively used in education. & 3.85 & 1.016 & $.713^{*}$ & .766 \\
\hline 8 & Authentic learning makes lessons more enjoyable. & 3.90 & .992 & $.739 *$ & .779 \\
\hline 12 & I think that the authentic tasks given to the students are effective in learning. & 3.89 & 1.057 & $.669^{*}$ & .700 \\
\hline 13 & I enjoy preparing a course environment in which authentic tasks appear. & 3.69 & 1.040 & $.749 *$ & .807 \\
\hline 14 & I try to prepare lesson plans involving authentic tasks and activities. & 3.60 & 1.057 & $.694^{*}$ & .822 \\
\hline 16 & I try to use authentic learning and evaluation in my lessons as much as possible. & 3.26 & 1.079 & $.688^{*}$ & .786 \\
\hline 18 & I think that authentic assessment and evaluation is also instructive for students. & 3.88 & .951 & $.693^{*}$ & .758 \\
\hline 19 & I would like to learn everything about authentic assessment and evaluation. & 4.00 & 1.065 & $.686^{*}$ & .714 \\
\hline 20 & $\begin{array}{l}\text { I think that the effectiveness of teaching activities will increase with the implementation of } \\
\text { task }\end{array}$ & 3.71 & 1.083 & $.659 *$ & .767 \\
\hline \multicolumn{6}{|c|}{ Factor 2 - Negative Approach } \\
\hline 2 & I regard authentic learning environments as unnecessary to be included in the curriculum. & 4.62 & .713 & $.544^{*}$ & .804 \\
\hline 5 & I do not prefer to use authentic learning environments unless it is really necessary. & 4.41 & .924 & $.590^{*}$ & .703 \\
\hline 7 & Authentic learning activities impose an unnecessary burden to the teachers. & 4.56 & .759 & $.550^{*}$ & .684 \\
\hline 9 & $\begin{array}{l}\text { I think it would be better to do regular lectures instead of conducting activities included in } \\
\text { authentic learning. }\end{array}$ & 4.17 & 1.160 & $.484 *$ & .733 \\
\hline 10 & $\begin{array}{l}\text { I think that authentic learning activities are not effective in learning and they are } \\
\text { unnecessary. }\end{array}$ & 4.60 & .724 & $.572 *$ & .839 \\
\hline 11 & I think that authentic learning environments will weaken my authority in the classroom. & 4.45 & .903 & $.527 *$ & .666 \\
\hline 15 & Authentic learning is not interesting. & 4.61 & .759 & $.540^{*}$ & .704 \\
\hline 17 & Authentic assessment and evaluation is not within my area of interest. & 4.45 & .909 & $.585^{*}$ & .636 \\
\hline
\end{tabular}

The scale which was identified as two-factor scale in the exploratory factor analysis was also applied to confirmatory factor analysis. In the confirmatory factor analysis, goodness of fit index (GFI), adjusted goodness of fit index (AGFI), normed fit index (NFI), standardized root-mean-square residual (SRMR), and root mean square error of approximation (RMSEA) and comparative fit index (CFI) were considered. Acceptable threshold values of the commonly used fit indexes and fit values of the proposed model are shown in Table 8 (Schermelleh-Engel \& Moosbrugger, 2003; Erdoğan, Bayram, and Deniz, 2007).

Table 8. Confirmatory Factor Analysis Results

\begin{tabular}{lllc}
\hline Fit Measure & Good Fit & Acceptable Fit & Suggested Model Values \\
\hline RMSEA & $0.00<\mathrm{RMSEA}<0.05$ & $0.05<\mathrm{RMSA}<0.10$ & 0.078 \\
SRMR & $0.00<\mathrm{SRMR}<0.05$ & $0.05<\mathrm{SRMR}<0.10$ & 0.067 \\
GFI & $0.95<\mathrm{GFI}<1.00$ & $0.90<\mathrm{GFI}<0.95$ & 0.895 \\
AGFI & $0.90<\mathrm{AGFI}<1.00$ & $0.85<\mathrm{AGFI}<0.90$ & 0.870 \\
NFI & $0.95<\mathrm{NFI}<1.00$ & $0.90<\mathrm{NFI}<0.95$ & 0.893 \\
CFI & $0.95<\mathrm{CFI}<1.00$ & $0.90<\mathrm{CFI}<0.95$ & 0.901 \\
RFI & $0.90<\mathrm{RFI}<1.00$ & $0.85<\mathrm{RFI}<0.90$ & 0.865 \\
\hline
\end{tabular}

Confirmatory factor analysis results are seen in Table 8 . The similarity ratio chi-square statistic was found as $\mathrm{x}^{2}$ 
$(181)=399.712, p<0.01$. Root mean square error of approximation $($ RMSEA $)=0.078$; standardized root mean residual squares average $(\mathrm{SRMR})=0.067$; comparative fit index $(\mathrm{CFI})=0.901$; goodness of fit index $(\mathrm{GFI})=0.895$; adjusted goodness of fit index $(\mathrm{AGFI})=0.870$; normed fit index $(\mathrm{NFI})=0.893$; the relative fit index $(\mathrm{RFI})=0.865$. These findings support the factor structure of the attitude scale towards authentic learning environments and its evaluation. The results of confirmatory factor analysis showed a good agreement between model and the data. It was seen that RMSA, SRMR, AGFI, CFI and RFI values were acceptable, but GFI and NFI values were close to acceptable values. In general, it is possible to say that the model is in good agreement with the data, but this fit is not perfect. The diagram of the 2-factor model is shown below (Figure 2).

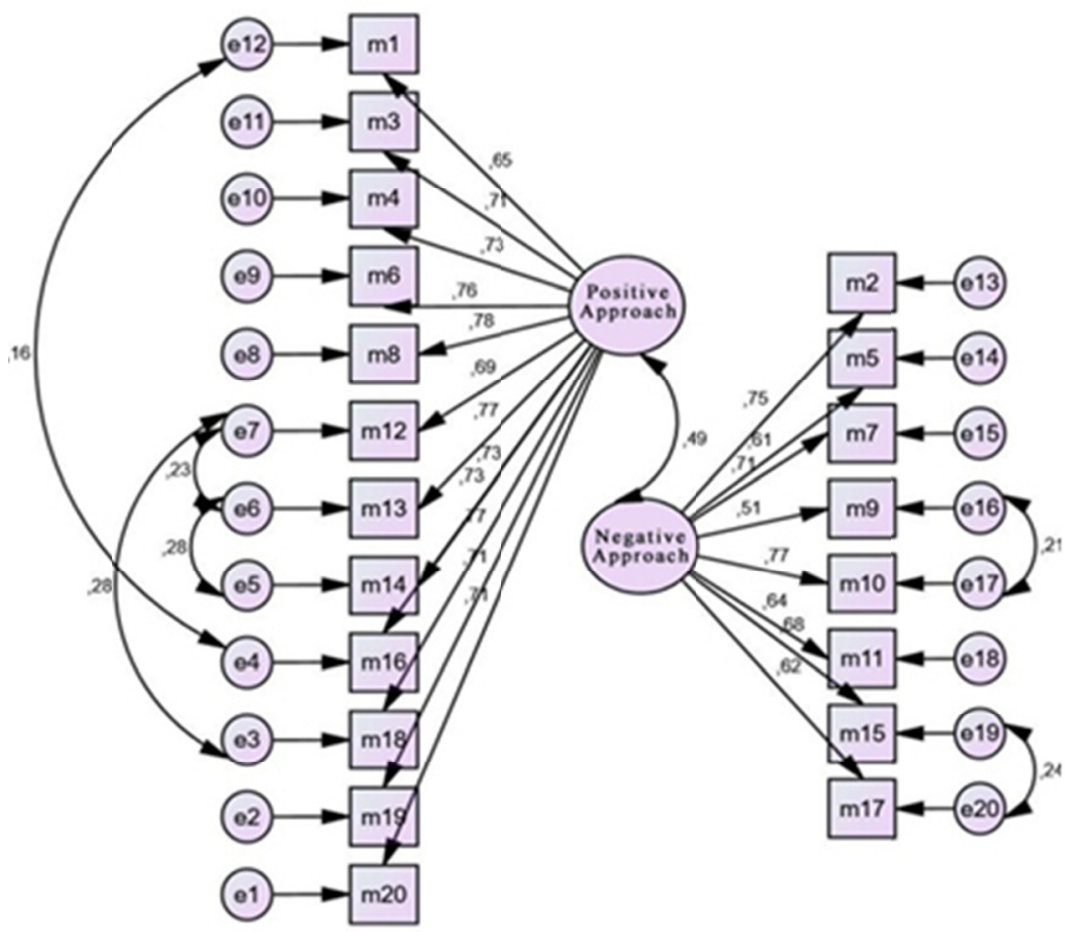

Figure 2. Two-Factor Path Diagram of the Scale

It is seen that the covariances among some items have been formed in Figure 2. The formed covariances for "positive items" are between " $\mathrm{m} 1$ and $\mathrm{m} 16$ ", "m18 and $\mathrm{m} 12$ ", " $\mathrm{m} 12$ and $\mathrm{m} 13$ " and " $\mathrm{m} 13$ and $\mathrm{m} 14$ ". These items also include the expressions intended for the purpose. Therefore, even if the expressions are different, the given answers are expected to be coherent with each other. Similar condition is also valid the items for negative attitude. A covariance has been created between " $\mathrm{m} 9$ and $\mathrm{m} 10$ ", " $\mathrm{m} 15$ and $\mathrm{m} 17$ ".

\section{Discussion}

Teaching science topics associated to real life will also increase the students' achievement towards science. Learning science in one's own life, finding out solutions and reporting them is one of the most important goals of the science curriculum. Teachers play the most important role here. A well-equipped teacher will provide further guidance to the students. One of the most effective ways to create such environments is authentic learning. Teaching should be well planned and evaluation should cover the process. Herein, teachers' attitudes towards authentic learning and evaluation are of great importance. In this context, it was aimed to develop a valid and reliable measurement tool to determine teachers' attitudes towards authentic learning environments and evaluation.

The development stage of the scale was discussed in detailed in terms of content, structure and face validity. While preparing the scale items, written opinions of 15 prospective teachers who were not included in the research sample towards authentic learning and evaluation were obtained. In addition to the opinions, the literature on the authentic learning was reviewed and total 40 items (18 negative 22 positive attitudes) including "knowing, using and applying" were created. For the scale, opinions of 2 field experts were asked and corrections, additions/subtractions were made. Considering the opinions of the field experts, 3 items were excluded from the scale and the remaining 37 items were applied to the study group consisting of 202 teacher candidates.

The data obtained were subjected to an anti-image correlation analysis to check the conformity. Three items with values below or near .50 were excluded. In addition, Kaiser-Meyer-Olkin (KMO) and Bartlett's test were used to check 
adequacy of the obtained data to factor analysis and sample size. KMO value was found to be .903 indicating a marvelous adequacy. On the other hand, according to Barlett's test results, inter-class correlation was found to be high $\left(x^{2}=2350.067 ; p<0.01\right)$. An exploratory factor analysis was performed to the data that were found to be appropriate for the sample. Four items with factor load value less than or close to $0.50,3$ items consisting of a single sub-dimension, and 1 item having close values to each other in more than one sub-dimension were excluded. Final scale consisted of 20 items. The reliability coefficient of the 20-item scale (Cronbach Alpha) was determined as 0.931.

Confirmatory factor analysis was applied to the 2 -factor scale. The similarity ratio chi-square statistic was found as $\mathrm{x}^{2}$ $(181)=399.712, \mathrm{P}<0.01$. Root mean square error of approximation (RMSEA) $=0.078$; standardized root mean residual squares average $(\mathrm{SRMR})=0.067$; comparative fit index $(\mathrm{CFI})=0.901$; goodness of fit index $(\mathrm{GFI})=0.895$; adjusted goodness of fit index $(\mathrm{AGFI})=0.870$; normed fit index $(\mathrm{NFI})=0.893$; the relative fit index $(\mathrm{RFI})=0.865$. The results obtained showed that the model is in good agreement with the data. While RMSA, SRMR, AGFI, CFI and RFI values were within acceptable range, GFI and NFI values were close to acceptable values. In general, it is possible to say that the model is in good agreement with the data, but this fit is not perfect. According to the analysis results, it can be concluded that the attitude scale developed towards authentic learning environments and evaluation is a valid and reliable scale.

Authentic evaluation should be handled as a whole by combining it with authentic tasks. In this way, it is possible to evaluate the learning and the learning process at the same time (Bektaş and Horzum 2010). In order to make an authentic evaluation, the teacher needs to have sufficient knowledge about the evaluation. However, evaluation in this way may be meaningful. When evaluating the authentic tasks, alternative assessment evaluation techniques are frequently used (Koçyiğit and Zembat, 2013; Kılıç and Aydın 2014; Gürdoğan and Aslan, 2016). In this context, teachers' attitudes towards such evaluations are of vital importance. The planning and implementation of the alternative assessment evaluation takes much more time than that in classical evaluation and this creates reluctance in some teachers (Gürdoğan and Aslan, 2016). Attitude scales that are valid and reliable will be useful for the determination of such situations and the planning of the teaching. It can be said that the scale developed in this study can be used and use for teacher candidates and teachers.

\section{Acknowledgements}

In this study, presented as oral presentation to "The Ninth International Congress of Educational Research, Ordu, Turkey / May 11-14, 2017".

\section{References}

Bektaş, M., \& Horzum, M. B. (2010). Otantik öğrenme [Authentic learning], Ankara: Pegem Akademi Yayınları.

Büyüköztürk, Ş., Bökeoğlu, Ç. Ö., \& Köklü, N. (2009). Sosyal bilimler için istatistik [Statistics for social sciences]. Ankara: Pegem Akademi.

Comrey, A. L., \& Lee, H. L. (1992). A first course in factor analysis, Hillsdale, New Jersey: Erlbaum.

Dewey, J. (2007). Deneyim ve eğitim [Experience and education]. Çeviren: S. Akıllı. Ankara: ODTÜ Yayıncılık A.Ş.

Erdoğan, Y., Bayram, S., \& Deniz, L. (2007). Web based instruction attitude scale: Explanatory and confirmatory factor analyses. Uluslararası Insan Bilimleri Dergisi, 4(2), 1-14.

Fer, S., \& Cırık, İ. (2007). Yapılandırmacı öğrenme: Kuramdan uygulamaya [Constructivist learning: Applying from theory to theory]. İstanbul: Morpa yayıncilik.

Fook, C. Y., \& Sidhu, G. K. (2010). Authentic Assesment and Pedagogial Strategies İn Higher Education, Journal of Social Science, 6(2), 153-161. https://doi.org/10.3844/jssp.2010.153.161

Gürdoğan, M., \& Aslan, A. (2016). Opinions of classroom teacher candidates about the authentic learning approach. Fen Eğitimi ve Araştırmaları Derneği Fen Bilimleri Öğretimi Dergisi, 4(2), 114-140.

Kalaycı, Ş. (2010). Factor analysis. SPSS applied multivariate statistical techniques. (Edt: Ş. Kalaycı) Ankara: Asil Yayın Dağıtım.

Kılıç, R. (2014). Evaluation of knowledge, attitudes and opinions about authentic measurement and evaluation methods of elementary school I level teachers. Marmara Üniversitesi, Eğitim Bilimleri Enstitüsü. Yayınlanmamış doktora tezi, İstanbul.

Kılıç, R., \& Aydın, O. (2014). An Investigation of Primary School Teachers ' Knowledge and Attitudes for Authentic Assessment and Evaluation Methods. Turkish Studies-International Periodical for the Languages, Literature and History of Turkish or Turkic, ISSN, 1308-2140.

Koçyiğit, S., \& Zembat, R. (2013). The Effects of the Authentic Task on Preservice Teachers' Achievement. Hacettepe 
Üniversitesi Eğitim Fakültesi Dergisi, 28(28-3).

Küçüktepe, C. (2010). Basic characteristics of primary education. (Editör: Oktay, A.) İlköğretime Hazırlık ve İlköğretim Programlar1, 1. Bask1: Ankara: An1 yayıncılık.

Schermelleh-Engel, K., \& Moosbrugger, H. (2003). Models: Tests of Significance and Descriptive, Psychological Research Online, 8(2).

Şencan, H. (2005). Reliability and validity in social and behavioral assessments. Ankara: Seçkin Yayıncılık.

Tan, Ş. (2009). Measurement and evaluation in teaching, KPSS el kitabı. Ankara: PegemA yayıncılık.

Tavşancıl, E. (2002). Measuring attitudes and data analysis with SPSS, Ankara: Nobel Yayıncılık. 
APPENDIX. Attitude Scale towards Authentic Learning Environments and its Evaluation

The following are statements that describe attitudes and behaviors towards authentic learning and assessment. These expressions may be those that identify you, or those that do not. Please read carefully each item and mark the option that best describes your situation. Your answers are not true or false, and how important your answers represent you. Your answers will only be used for this research and the information will remain hidden.

Thank you very much for your help and information. Dr. Murat ÇETINKAYA

\begin{tabular}{|c|c|c|c|c|c|c|}
\hline & \multirow{2}{*}{$\boldsymbol{F}$} & \multirow{2}{*}{$\frac{\theta}{2}$} & \multirow{2}{*}{$\stackrel{D}{3}$} & \multirow{2}{*}{$\frac{4}{4}$} & \multirow{2}{*}{ 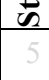 } \\
\hline 1 & I love creating authentic learning environments when teaching unit topics. & & & & & \\
\hline 2 & I regard authentic learning environments as unnecessary to be included in the curriculum. & 1 & 2 & 3 & 4 & 5 \\
\hline 3 & I would like to use authentic learning environments in all my courses. & 1 & 2 & 3 & 4 & 5 \\
\hline 4 & Authentic learning method should be used in other courses (mathematics, science). & 1 & 2 & 3 & 4 & 5 \\
\hline 5 & I do not prefer to use authentic learning environments unless it is really necessary. & 1 & 2 & 3 & 4 & 5 \\
\hline 6 & I think that authentic learning method can be effectively used in education. & 1 & 2 & 3 & 4 & 5 \\
\hline 7 & Authentic learning activities impose an unnecessary burden to the teachers. & 1 & 2 & 3 & 4 & 5 \\
\hline 8 & Authentic learning makes lessons more enjoyable. & 1 & 2 & 3 & 4 & 5 \\
\hline 9 & $\begin{array}{l}\text { I think it would be better to do regular lectures instead of conducting activities included in } \\
\text { authentic learning. }\end{array}$ & 1 & 2 & 3 & 4 & 5 \\
\hline 10 & I think that authentic learning activities are not effective in learning and they are unnecessary. & 1 & 2 & 3 & 4 & 5 \\
\hline 11 & I think that authentic learning environments will weaken my authority in the classroom. & 1 & 2 & 3 & 4 & 5 \\
\hline 12 & I think that the authentic tasks given to the students are effective in learning. & 1 & 2 & 3 & 4 & 5 \\
\hline 13 & I enjoy preparing a course environment in which authentic tasks appear. & 1 & 2 & 3 & 4 & 5 \\
\hline 14 & I try to prepare lesson plans involving authentic tasks and activities. & 1 & 2 & 3 & 4 & 5 \\
\hline 15 & Authentic learning is not interesting. & 1 & 2 & 3 & 4 & 5 \\
\hline 16 & I try to use authentic learning and evaluation in my lessons as much as possible. & 1 & 2 & 3 & 4 & 5 \\
\hline 17 & Authentic assessment and evaluation is not within my area of interest. & 1 & 2 & 3 & 4 & 5 \\
\hline 18 & I think that authentic assessment and evaluation is also instructive for students. & 1 & 2 & 3 & 4 & 5 \\
\hline 19 & I would like to learn everything about authentic assessment and evaluation. & 1 & 2 & 3 & 4 & 5 \\
\hline 20 & I think that the effectiveness of teaching activities will increase with the implementation of task & 1 & 2 & 3 & 4 & 5 \\
\hline
\end{tabular}

\section{Copyrights}

Copyright for this article is retained by the author(s), with first publication rights granted to the journal.

This is an open-access article distributed under the terms and conditions of the Creative Commons Attribution license which permits unrestricted use, distribution, and reproduction in any medium, provided the original work is properly cited. 